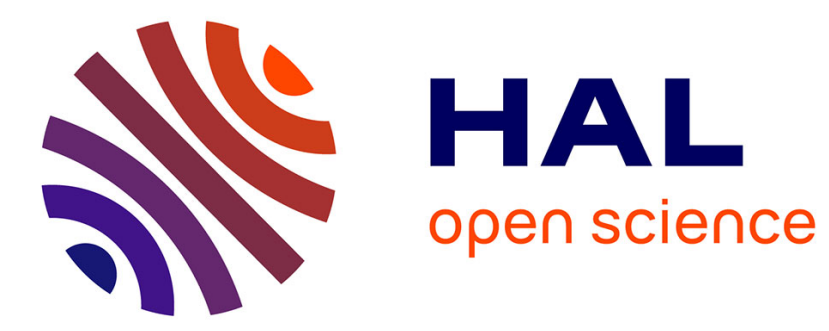

\title{
Hyaluronic Acid - Hydroxychloroquine Conjugate Proposed for Treatment of COVID-19
}

Riaz Khan, Vincent Aroulmoji

\section{To cite this version:}

Riaz Khan, Vincent Aroulmoji. Hyaluronic Acid - Hydroxychloroquine Conjugate Proposed for Treatment of COVID-19. International journal of advanced Science and Engineering, 2020, 06, pp.1469 1471. 10.29294/ijase.6.4.2020.1469-1471 . hal-03093028

\section{HAL Id: hal-03093028 \\ https://hal.science/hal-03093028}

Submitted on 3 Jan 2021

HAL is a multi-disciplinary open access archive for the deposit and dissemination of scientific research documents, whether they are published or not. The documents may come from teaching and research institutions in France or abroad, or from public or private research centers.
L'archive ouverte pluridisciplinaire HAL, est destinée au dépôt et à la diffusion de documents scientifiques de niveau recherche, publiés ou non, émanant des établissements d'enseignement et de recherche français ou étrangers, des laboratoires publics ou privés. 


\section{Hyaluronic Acid - Hydroxychloroquine Conjugate Proposed for Treatment of COVID-19}

\section{Riaz Khan ${ }^{1 *}$ \& Vincent Aroulmojii ${ }^{2}$}

${ }^{1}$ Rumsey, Old Bath Road, Sonning, Berkshire, RG4 6TA, England, United Kingdom

${ }^{2}$ Centre for Research \& Development, Mahendra Engineering College, Mahendhirapuri, Mallasamudram-637503, Namakkal District, Tamil Nadu, India

ABSTRACT: We propose to develop a drug conjugate from Hyaluronic acid (HA) biomaterial, which is present in extracellular matrices, the synovial fluid of joints, and Hydroxychloroquine (HCQ), which is being considered for the treatment of COVID-19 but it exhibits some toxicity, the HA-HCQ is expected to show reduced toxicity and enhance efficacy.

KEYWORDS: COVID-19, Hyaluronic acid, Hydroxychloroquine, drug delivery, drug conjugation

\section{INTRODUCTION}

A number of antiviral drugs are used for the treatment of different viral diseases; these include: Hydroxychloroquine for malaria, rheumatoid arthritis, and the same is now considered for the treatment of COVID-19; Lopinavir and Ritonavir for HIV/AIDS and other antiretroviral; Favipiravir, antiviral drug with activity against RNA viruses, and effective against COVID-19; Remdesivir (GS.5734), originally considered for the Ebola virus disease, MERS and SARS Viruses (SARS-C0-2); Cyclodextrins, a sugar based polymers, show some promise in the treatment of COVID-19. However, almost all of these drugs exhibit some systemic toxicity.

Our objective is to modify one of the leading drugs, Hydroxychloroquine, considered for COVID-19, by conjugating it with hyaluronic acid to reduce its toxicity and increase its efficacy.

Hyaluronan also known as hyaluronic acid, HA [1] is a naturally occurring polysaccharide of a linear repeating disaccharide unit consisting of $\beta-(1 \rightarrow 4)$ linked D-glucopyranuronic acid and $\beta$ - $(1 \rightarrow 3)$-linked 2 acetamido-2-deoxy-D-glucopyranose (Fig. 1), which is present in extracellular matrices, the synovial fluid of joints, and scaffolding that comprises cartilage. Despite the simplistic structure of hyaluronan, it behaves quite differently from other glycosaminoglycans in its mechanism of synthesis, its size, its physico-chemical properties such as the network-forming, viscoelastic, and its charge characteristics are important to many biochemical properties of living tissues. It mediates its biological functions through specific protein receptors present on the different cell surfaces, which include CD44 [2], HARE [3], RHAMM [4], and LYVE [5].
Hyaluronan molecules are involved in the activation of signalling pathways that control cell proliferation, differentiation, adhesion and migration [6-12].

Our research work on specific conjugation of hyaluronic acid (Fig.1) with pharmacologically active compounds such as camptothecin, methotrexate, methylprednisolone, propofol led to a number of drugs for the treatment of diseases such as cancer, arthritis, osteoporosis; hyaluronic acid is not only interesting because of its biocompatibility and bio absorbability, but also because of its own therapeutic efficacy [13$15]$.

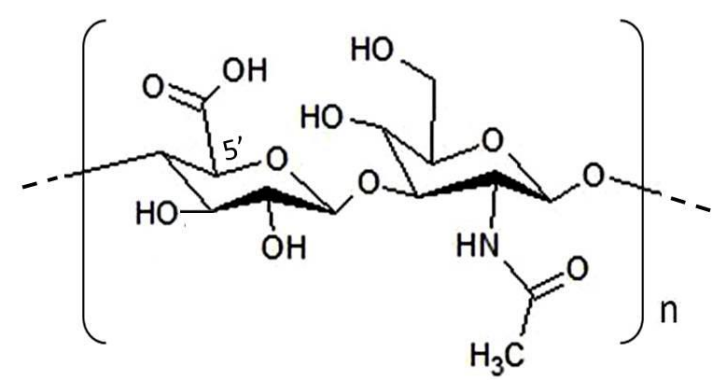

Figure 1. Hyaluronic Acid (HA)

\section{Why HA-HCQ Conjugates?}

In the light of our research on HA-conjugates with a variety of pharmaceutical compounds to yield drugs with specific targeting strategy, we reasoned the possible application of the conjugated HCQ to HA (Fig.1), to study its biological activity against the COVID-19. The advantages envisaged in this strategy to

$\begin{array}{ccc} & { }^{*} \text { Corresponding Author: riazazami@gmail.com } \\ \text { Received: } 15.03 .2020 & \text { Accepted: } 25.03 .2020 & \text { Published on: } 27.03 .2020\end{array}$ 
conjugate the drug Hydroxychloroquine with hyaluronic acid to afford HA-HCQ (Fig.3), are to reduce the intrinsic toxicity and to increase its bioavailability, localization and controlled release of the drug, and enhance the efficacy of the conjugated drug (Fig. 3).

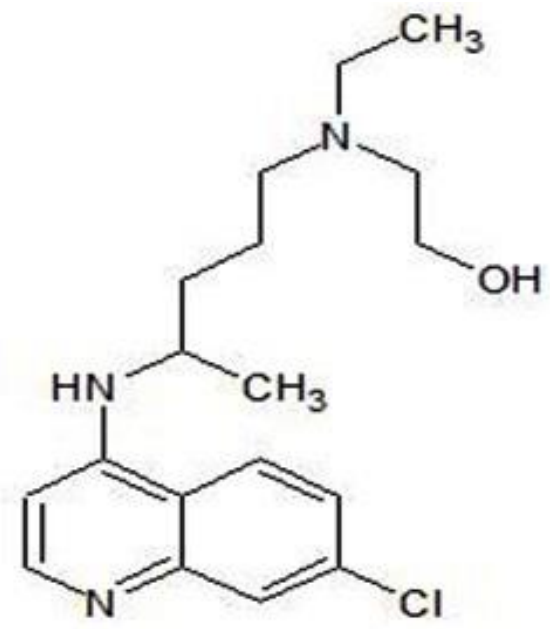

Figure 2. Hydroxychloroquine (HCQ)

The conjugation of HCQ (Fig.2) to hyaluronic acid (Fig.1) can be achieved through the hydroxyl group of the HCQ by a variety of linkages known in the classical organic chemistry. However, initially, we have chosen the simplest approach to link the hydroxyl group of the compound (Fig. 2) to hyaluronic acid (Fig.1) through the C5'carboxylic group of the glucuronic moiety forming and ester linkage. For the detail methodology of our proposed strategy, see our patent [15] on the conjugation methylprednisolone with HA.

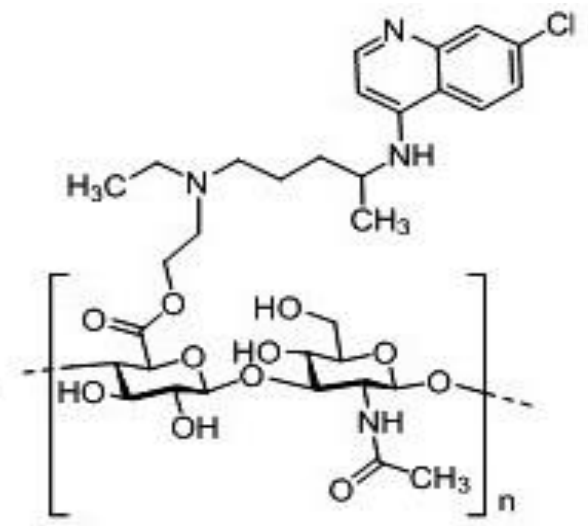

Figure 3. Hyaluronic Acid-Hydroxychloroquine conjugate

\section{CONCLUSION}

A number of "HA-HCQ" drug conjugates, using different molecular weight of hyaluronic acid and different degree of substitution of HCQ in the conjugates, will be prepared and evaluated against COVID-19.

\section{ACKNOWLEDGEMENT}

Dr.Riaz Khan is indebted to EU Framework Programme 6 (FP6) for providing the EU Fellowship and for financial support from EU FP6 Research Programme that made it possible for him to come to work in the AREA Science Park, Trieste, Italy (19912010), on the Hyaluronic Acid conjugation programme of pharmaceutical significance.

\section{REFERENCES}

1) Jia Liu, Ruiyuan Cao, Mingyue $\mathrm{Xu}, \mathrm{Xi}$ Wang, Huanyu Zhang, Hengrui $\mathrm{Hu}$, Yufeng Li1, Zhihong $\mathrm{Hu}, \mathrm{Wu}$ Zhong and Manli Wang, 2020. Hydroxychloroquine, a less toxic derivative of chloroquine, is effective in inhibiting SARS-CoV-2 infection in vitro, Cell Discovery, 6:16

2) Underhill C,1992. CD44: the hyaluronan receptor, J Cell Sci., Oct 103 ( Pt 2):293-288.

3) Pandey, MS., Weigel, PH, 2014. Hyaluronic Acid Receptor for Endocytosis (HARE)-mediated Endocytosis of Hyaluronan, Heparin, Dermatan Sulfate, and Acetylated Low Density Lipoprotein (AcLDL), but Not Chondroitin Sulfate Types A, C, D, or E, Activates NF- $\kappa \mathrm{B}$-regulated Gene Expression J Biol. Chem., Jan 17, 289(3): 1756-1767.

4) Park,D., Youngmi Kim., Hyunah Kim., Kyungjong Kim., Yun-Sil Lee., Jongseon Choe., Jang-Hee Hahn., Hansoo Lee., Jongwook Jeon., Chulhee Choi YoungMyeong Kim., Dooil Jeoung,2012. Hyaluronic Acid Promotes Angiogenesis by Inducing RHAMM-TGF $\beta$ Receptor Interaction via CD44-PKCS, Molecules and Cells, 33, 563-574.

5) Lawrance, W., Banerji S, Day AJ., Bhattacharjee S., Jackson DG., 2016. Binding of Hyaluronan to the Native Lymphatic Vessel Endothelial Receptor LYVE-1 Is Critically Dependent on Receptor Clustering and Hyaluronan Organization. J Biol. Chem. Apr 8, 291(15), 8014-30.

6) Stern, R, Asari, AA, Sugahara, KN. 2016. Hyaluronan fragments: an information-rich system. European Journal of Cell Biology, 85, 699715.

7) Aruffo, A., Stamenkovic, I., Melnick, M., Underhill, CB., Seed, B. 1990. CD44 is the principal cell surface receptor for hyaluronate. Cell, 61, 13031313.

8) Turley, EA, Noble, PW, Bourguignon, LY.2002. Signaling properties of hyaluronan receptors. The Journal of Biological Chemistry, 277, 4589-4592 
9) Yamada T, Kawasaki T. 2005. Microbial synthesis of hyaluronan and chitin: New approaches. Journal of Bioscience and Bioengineering, 99, 521-528.

10) Goueffic Y., Guilluy C., Guerin P., Patra P., Pacaud P., Loirand G.2006. Hyaluronan induces vascular smooth muscle cell migration through RHAMMmediated PI3K-dependent Rac activation. Cardiovascular Research, 72, 339-348.

11) Kyosseva SV., Harris EN., Weigel PH.2008. The hyaluronan receptor for endocytosis mediates hyaluronan-dependent signal transduction via extracellular signal-regulated kinases. The Journal of Biological Chemistry, 283, 15047-15055.

12) Maxwell CA., McCarthy J., Turley E.2008. Cellsurface and mitotic-spindle RHAMM: moonlighting or dual oncogenic functions? Journal of Cell Science, 121, 925-932.
13) Erminio Murano., Danilo Perin., Riaz Khan., Massimo Bergamin. 2011. Hyaluronan: From Biomimetic to Industrial Business Strategy (a Review), Natural Products Communications, 6(4) 555-572.

14) Khan, R., Mahendhiran,B., Aroulmoji,V. 2013. Chemistry of Hyaluronic Acid and Its Significance in Dug Delivery Strategies, International Journal of Pharmaceutical Sciences and Research, 4(10): 3699-3710.

15) Khan, R., Konowicz, P. A. 1996. A dicarboxylic acid hemiester or hemiamide with a pharmacologically active compound and with hyaluronic acid or with a hyaluronic acid ester, a process for its preparation and a controlled release medicament containing this derivative. WO 1996035721A1. 